\title{
John Lindbeck: A Memorial
}

The field of China studies has suffered a tragic loss with the death, on 9 January, of John M. H. Lindbeck, Director of the East Asian Institute at Columbia University. John's death came at the peak of his career. He was currently deeply involved, as he has been for more than a decade, in a wide variety of activities relating to the development of contemporary China studies, both in the United States and internationally. At the time of his death, he was completing a report for the Ford Foundation analysing the growth of China studies since 1960 and assessing the needs and opportunities in the future, in the United States and internationally. In preparing this report he had travelled widely last year, visiting universities and research centres throughout Asia and Europe. Just before his death he had finished editing a major volume on Government in China: The Management of a Revolutionary Society, to be published this spring by the University of Washington Press.

John Lindbeck was a talented scholar and teacher. He had written articles for a wide range of journals and had contributed important chapters to four books, as well as editing the volume mentioned above. His particular interest was in the organization and development of science in China. As a teacher, he felt a great sense of responsibility to his students: one of his often-stated goals was to help ensure that the next generation of scholars on China would be better prepared to understand Chinese politics and society than those of his own generation. His special genius, however, was as a leader, organizer and administrator of research and academic programmes. As much as, or more than, any other single individual, he was at the forefront of the process of stimulating, planning, promoting and leading the exciting expansion of contemporary China studies during the past decade. He played a major role in developing social science work on contemporary China at two of the principal American university centres of China studies; at Harvard (as Associate Director of the East Asian Research Center from 1959-67) and at Columbia (as Director of the East Asian Institute, from 1967 onwards). In addition, he was an organizer and leader of many national and international organizations and programmes. These included, amongst others: the Joint Committee on Contemporary China (of the American Council of Learned Societies and the Social Science Research Council) which he chaired from 1964 to 1970; the Committee on Scholarly Communication with Mainland China (of the American Academy of Sciences and ACLS and SSRC) which he chaired from 1968 onwards: the Advisory Committee on the Hong Kong Universities Service Center, the Board of the Chinese Materials and Research Aids Service Center on Taiwan (of the Association for Asian Studies) and the Board of the National Committee on United States-China Relations and many others. Not only was he active in all of these organizations; in most of them he carried the principal responsibility and burden of work.

Both his background and personal qualities propelled John Lindbeck into this position of leadership in the China field. He was born in Honan, China, in 1915, the son of missionaries, and during his childhood he acquired an intimate knowledge of things Chinese and a deep respect for the Chinese people. In his university education in the United States, he 
was thoroughly trained as a scholar in political science and China studies, obtaining his Ph.D. from Yale in 1948 after doing graduate work at Harvard and Michigan as well as Yale. From 1949-52 he taught political science and Far Eastern area studies at Yale and was director of undergraduate Far Eastern area studies. He then spent six years as Public Affairs Adviser on Chinese and Overseas Chinese Affairs in the Department of State before returning to academic pursuits at Harvard and Columbia. This experience in government enabled him, later, to do much to bridge the gap between scholars and officials, just as his broad academic interests and experience helped him to serve as a bridge linking people in many different disciplines and institutions.

John had a strong sense of mission and was totally committed to objective scholarship and to the task of raising the level of knowledge and understanding of China, not only in the United States but throughout the world. He had a broad vision of the goals to be pursued, a remarkable sense of what was needed to spur the developmental process, a rare feeling for how to create and operate institutions and an unerring instinct for how to bring men together to engage in important common tasks. He believed that scholarship transcends all political and geographical barriers and looked forward to the day when there would be a genuinely international community of scholarship on China. His broad international outlook will be testified to, I know, by scholars in many parts of the globe who were beneficiaries of his counsel and support.

With his multiple responsibilities, it is quite accurate to say, I think, that John Lindbeck gave his life, in a very literal sense, to the field of contemporary China studies, and all of us-including generations of China scholars still to come-are deeply in his debt. Those who knew him well have suffered a great personal loss, for he was a gentle man of uncommon wisdom and a warm and steadfast friend. In addition, however, the entire field of China scholarship, including hundreds of scholars who did not know him personally, will feel the loss, since the qualities of leadership which he brought to the field are not easily replaceable.

\section{A. DoAK BARnetT}

